\title{
他者による着座姿勢の感情判断推定システムに関する研究 EMOTION ESTIMATING SYSTEM OF SITTING POSTURES BY OTHERS
}

\author{
柴田滝也* \\ Tatsuya SHIBATA
}

\begin{abstract}
Not only facial expressions but also body gestures and postures play an important role in non-verbal communication. Facial expressions are based on two factors: arousal and pleasant emotions, while it is not clear that body gestures and postures have the same structure as the facial expressions have. We indicate that (1) the sitting postures have the same emotion structure as facial expressions and (2) can be measured by pressure sensors on a chair and accelerometers on the body, which predict the emotion factors. We find the sitting postures have three semantic factors: "arousal", "pleasantness", and "dominance", so emotion expressions of the sitting postures are similar to those of the facial expressions. Their difference is "dominance" expressed by not the main body but the body parts such as arms and legs. We conclude that (1) the three factors can be measured with the proposed sensors and (2) the body trunk and the body parts: neck, arms, and legs are important.
\end{abstract}

\section{Keywords : Sitting Posture, Emotion Estimation, Pressure Sensor, Accelerometer Sensor 着座姿勢, 感情推定, 圧力センサ, 加速度センサ}

\section{1. はじめに}

本研究は人の発する非言語情報(特に着座姿勢)から感情を推定す るモデルを作成し，圧力センサや加速度センサを用いた着座姿勢計 測装置で, ユーザの不快感を減らし,安価かつ容易に着座姿勢の計測 を行い，リアルタイムで感情を推定するシステムの構築を目的とす る。

人は日常生活で相手とコミュニケーションを行う際，相手の言語 情報とともに非言語情報をもとに円滑なコミュニケーションを行う。 表情や動作・姿勢などの非言語情報から，人の感情を読み取る理論 の研究は, Baron-Cohenの mind reading system[1]に代表される ように盛んに行われている。工学の分野では, Ekman が提唱する 喜び，怒り，悲しみ，嫌悪，驚き，恐怖からなる基本 6 感情モデル [2]や Russell の覚醒度(Arousal) と快適度(Valence)の 2 軸から構成 される感情円環モデル[3]の応用があり, 伊藤ら [4]は感性会話ロボッ 卜 ifbotに, Russell の感情円環モデルに当てはまる表情を与え, 浦 濱ら[5]も Russell の感情円環モデルをもとに顔画像解析から快・不 快を計測している。表情から感情を読み取る研究が多く行われてい る背景としては, 感情についての判断は身体の姿勢・動作よりも顔 の表情を見て行うというEkman らの指摘がある。一方, Bull ら [6] は，会話においては動作などの非言語情報が同期している点を重視 している。本研究では，表情は感情を欺瞞する事が一部あり，姿勢 に真の感情が表出する場合があると仮定し, 着座姿勢に表出する感
情を人はどのように判断・評価しているのかを明らかにするため, 着座姿勢から受ける感情判断の分析とモデル生成を試みる。

姿勢に関しては, 渡辺ら [7]は長時間の着座時における人間の支持 形態の変化について, 上体の前傾・後傾, 臂部 (尻) の前縁 (前方) · 後縁 (後方) , 脚部の投脚 $($ 前方 $)$-垂下 (直立) ・膝組からなる組み 合わせ 12 種類を抽出し，分析を行っている．小林ら[8]は飲食店の 着座姿勢の特徵として, 脚を組む, 肘をつく, 上体の傾き（前傾・ 垂直・後傾）があることを明らかにした。Kleinsmith と Bianchi-Berthouze[9][10]は，予め用意した定型とゲーム操作時の 不定型の立位姿勢と感情の分析を行っており，接触型のセンサを用 いて身体部位間の角度や距離との関係を明らかにしている。さらに 立位姿勢の感情に関しては, 「快適度」,「覚醒度」,「力量度」,「防御 度」の 4 因子を抽出し，その因子と接触型センサによる身体部位の 物理量との関係を分析している。また，着座姿勢に関しては，鶴岡 ら[11]は椅子への座面全部の体圧分布と主観評価に正の，背もたれ 中央部に負の相関があることを示し，Kolich[12]は体圧分布と身体 特性から座り心地を予測するシステムを構築し, 藤巻[13]は体圧分 布のパターン変動と座り心地との関係分析を行っている。Mota と Picard[14]は椅子の座面に体圧センサを配置し，興味との関係を明 らかにしている。

しかし，立位姿勢からセンサを通して感情を推定できる一方，セ ンサ自体が高価かつ装着する必要がある。また，着座姿勢に関して

\footnotetext{
* 東京電機大学情報環境学部情報環境学科 教授·Ph.D.

Prof., Dept. of Information Environment, School of Information Environment, Tokyo Denki
} University, Ph. D. 
は, 座り心地の評価が多く, 感情の構造が明らかになっておらず, また, センサも面的に必要なため高価になる。そこで, 本研究では, 着座姿勢に焦点をあて, 感情の因子を明らかにするとともに, 安価 なセンサを用いて，まず，因子と身体部位およびセンサ值との関係 を明らかにするとともに，センサを用いた実時間感情判断推定シス テムの検証を行う。

我々の先行研究では, 観察者が正面から着座姿勢を見た場合と側 面から着座姿勢を見た場合の感情判断の相違については, 感情判断 の因子に差が生じなかった[15]。そこで, 本研究では, SD 法を用い て, パイプ椅子に着座した姿勢を側面から見た場合の感情判断因子 を分析することにより, 顔の表情や立位姿勢の感情判断因子との類 似点, 相違点を, および, 因子得点の分布により, 感情判断因子と 身体の部位や状態との関係を明らかにする。

さらに, 従来の研究において, 実時間で着座姿勢の状態を計測し, 感情を推定する手法はない。そこで, 感情判断因子と身体部位との 関係より, 身体部位の状態をセンサで計測することにより, 感情判 断因子や感情を推定するシステムを構築する。

\section{2. 実験 1 : 他者から見た側面の着座姿勢の感情分析 \\ 2. 1 実験目的および内容}

本人の感情より，他者から見た感情を分析する。理由としては， 本人の感情自体の意識化が困難と考え, 他者の感情の判断がより的 確になると考えた。また, 応用先としては, 遠隔地におけるコミュ ニケーション支援に用いることを考えており, 他人による感情推定 が重要であると判断した。

実験 1 は, パイプ椅子（図 1 a) を選択し, 着座姿勢の状態が判 断しやすい側面の着座姿勢について, 感情判断因子を抽出し, 感情 判断因子と物理量との関係分析を行う。渡辺らの着座姿勢の分類方 法を参考に, 上体の直立・後傾, 臂部の前縁・後縁, 脚部の投脚 · 垂下・膝組に加え, 新たに脚部の後方を追加した組み合わせ 16 着 座姿勢, さらに, 感情との関連で既往研究[9]から, 首の前傾・後傾 の 2 種類と腕組位置として脚部 - 胸部 - 頭部と上体の前傾の 4 種類 の組み合わせ 8 種類を追加し, 合計 24 着座姿勢（図 2 ）について 分析を行う。図 2 の (1)から 16は上体傾き/臂部位置/脚部状態」を, (17)から (22) は「着座姿勢(13)十頭部傾き/腕位置」を, (23), (24)「上体傾 き/頭部傾き/腕位置」を示す。
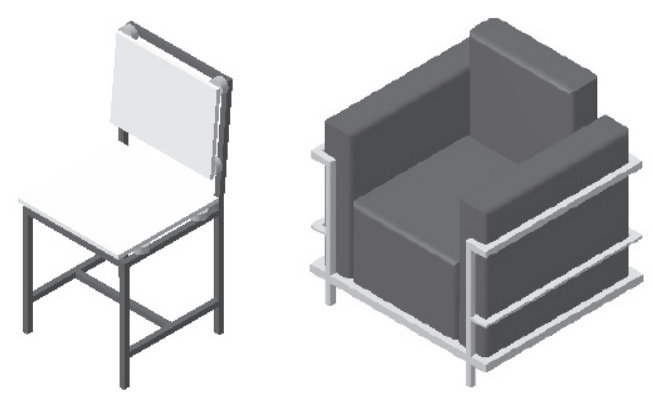

（a）実験 1 用のパイプ椅子

(b) 実験 2 用のソファ

図 1 椅子・ソファの形状

\section{実験 1 内容 :}

観察者： 20 代前半 13 名（男性：5名，女性：8 名） サンプル：パイプ椅子着座時の 24 着座姿勢（図 2 ） × 3 着座者 (A(身長 $166 \mathrm{~cm} /$ 座高 $74 \mathrm{~cm}), \mathrm{B}($ 身長 $165 \mathrm{~cm} /$ 座高 $75 \mathrm{~cm}), \mathrm{C}($ 身長 $166 \mathrm{~cm} /$ 座高 $85 \mathrm{~cm})$ ) =計 72 サンプル 画像をランダムにディスプレー上に表示

感情語： Russell の円環モデルに使われた 16 感情語（表 1) を用いた 7 段階評価（ランダムに評価）

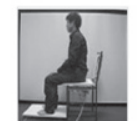

(1)直/前/垂

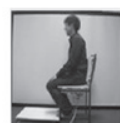

(7)直/後/後

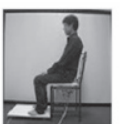

(13)後/後/垂
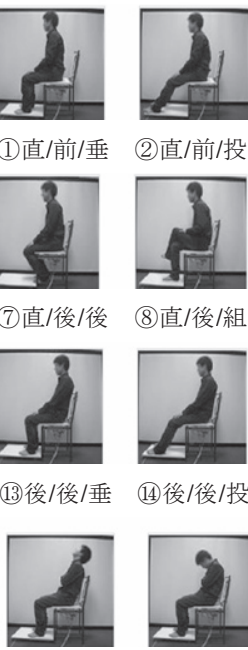

(2)直/前/投

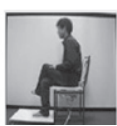

(8)直/後/組

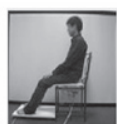

(14)後/後/投

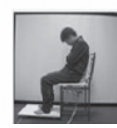

(19)(13)+後/胸 (20)(13)+前/胸
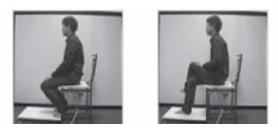

(4)直/前/組

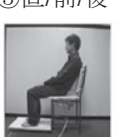

(9)後/前/垂

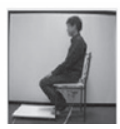

(15)後/後/後
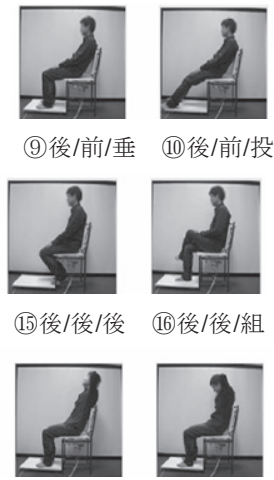

(10)後/前/投

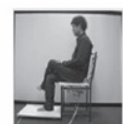

(16)後/後/組
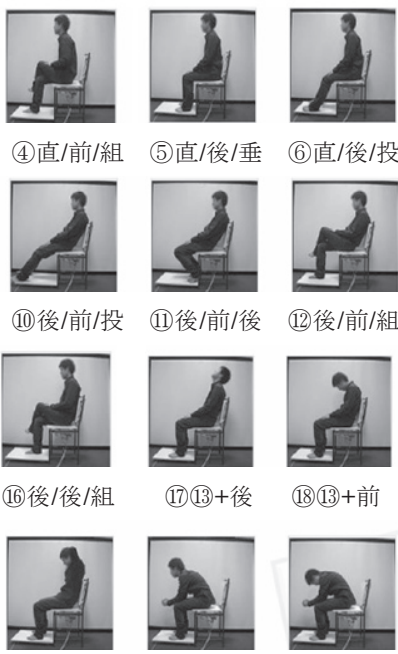

(5)直/後/垂 (6)直/後/投

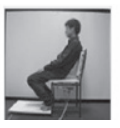

(11)後/前/後

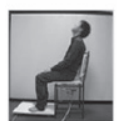

(17) (13) +後

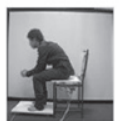

図 2 パイプ椅子着座時における姿勢サンプル（実験 1 ）

\section{2 感情判断因子と身体部位との定性関係分析}

72 着座姿勢サンプル画像 $(24$ 姿勢 $\times 3$ 名 $)$ に対する 16 感情語 について $1 \sim 7$ 点の評価值を割り当て, 全観察者の平均值を用いて 因子分析（主因子法）を用いて他者による着座姿勢の感情判断の因 子を分析した。固有值が 1 以上の 3 因子が抽出され, 表 1 に各感情 語の因子負荷量（バリマックス回転後）を示す。因子負荷量の絶対 值が 0.55 以上の感情語（灰色部）から，下記の 3 つの因子を抽 出し, 各着座姿勢の因子得点を計算した。この因子得点を感情判断 因子得点と呼ぶことにする。

表 1 着座姿勢の感情語の因子負荷量

\begin{tabular}{|l|r|r|r|}
\hline & 覚醒度 & \multicolumn{1}{|c|}{ 快適度 } & \multicolumn{1}{c|}{ 支配度 } \\
\hline 眠そうな & -.902 & -.229 & .088 \\
\hline 目覚めた & .895 & .331 & -.200 \\
\hline 興奮した & .888 & .077 & .081 \\
\hline 驚いた & .845 & .238 & -.156 \\
\hline 飽きた & -.806 & .103 & .447 \\
\hline 喜んだ & .661 & .550 & -.057 \\
\hline 不満足な & -.625 & -.378 & .597 \\
\hline 穏やかな & -.164 & .895 & -.150 \\
\hline 満足した & .363 & .825 & .073 \\
\hline 幸せな & .301 & .824 & -.127 \\
\hline 悲しんだ & -.538 & -.719 & -.073 \\
\hline 悩んだ & -.510 & -.609 & .342 \\
\hline いらいら & -.232 & -.241 & .886 \\
\hline 怒つた & .077 & .000 & .818 \\
\hline 緊張した & .630 & .014 & -.630 \\
\hline 恐れた & .118 & -.547 & -.569 \\
\hline
\end{tabular}


1. 覚醒度：「眠そうな」「目覚めた」などの身体活動に関係す る感情

2. 快適度：「幸せな」,「悲しんだ」などの快・不快に関係する 感情

3. 支配度：「いらいら」, 「緊張した」など自分のパーソナル・ スペースーの侵入に対する能動的に支配する・受動的に支 配されるに関係する感情

次に, 図 3 に側面の着座姿勢の感情判断因子得点のマッピングを 示寸。図 3 a の横軸が第一因子の「覚醒度」, 縦軸が第二因子の快適 度の因子得点（数值が低いほど「覚醒度」,「快適度」は高くなる） である。

図 $3 \mathrm{a}$ の「覚醒度」の因子得点分布から, 上体と首の角度によっ て「覚醒度」を判断していることが分かる。例えば，上体および首 の角度が垂直（直立）な場合は「覚醒度」が高く, 一方, 身体が後 傾, あるいは, 首が前傾あるいは後傾の場合は「覚醒度」が低くな る。

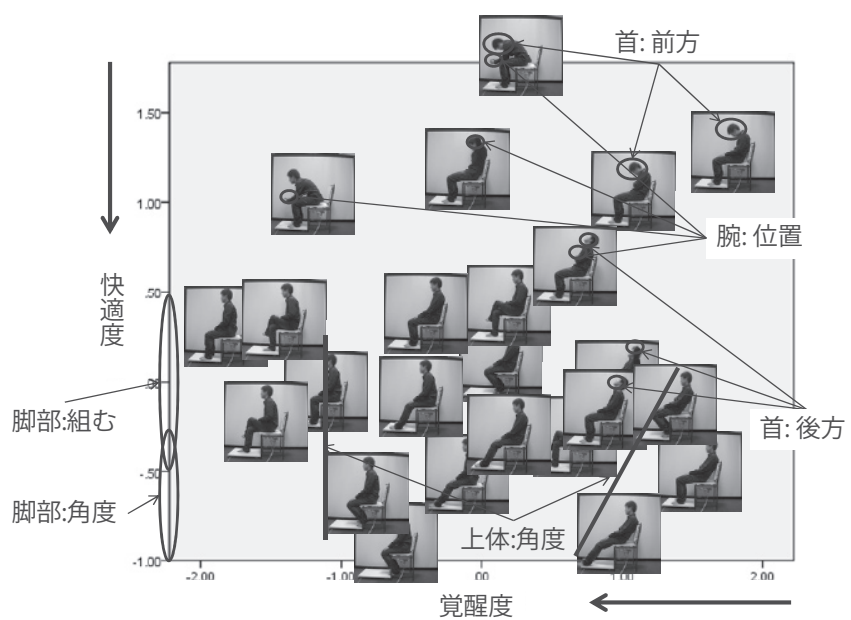

(a)「覚醒度」と「快適度」

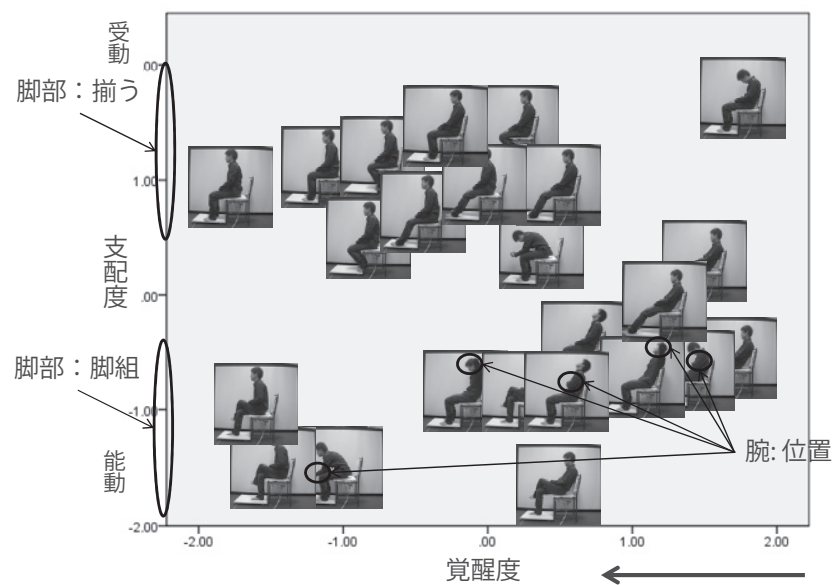

(b)「覚醒度」と「支配度」

図 3 側面の着座姿勢の感情判断因子得点のマッピング図

図 $3 \mathrm{a}$ の「快適度」の因子得点分布から, 首, 腕, 脚の状態亡「快 適度」と関係があることが分かる。例えば，脚が垂下でない，ある
いは, 脚組の状態は, 「快適度」は高くなり, 腕を前に出す, 組む, あるいは，首が前傾の状態では，「快適度」は低くなる。

図 $3 \mathrm{~b}$ の横軸が第一因子の「覚醒度」, 縦軸が第三因子の「支配度」 の因子得点である。「支配度」に関しては,「いらいら」，「怒った」 など自分のパーソナル・スペースへの侵入に対する能動的に支配す る感情表出方向がマイナスへ, 一方,「緊張した」,「恐れた」など自 分のパーソナル・スペースへの侵入に対して受動的に支配される感 情表出方向がプラスになる。図 $3 \mathrm{~b}$ の「支配度」の因子得点分布か ら, 脚組, 腕組など位置が通常の状態でない場合, パーソナル・ス ペースへの侵入を嫌い，他者への能動的な支配を示し，一方，脚が 揃う通常の状態である場合，他者からの受動的な支配を示す。

\section{3. 実験 2：感情判断因子と物理量との定量関係分析 \\ 3. 1 実験目的および内容}

上記の実験結果を踏まえて, 実時間で感情を推定するために, セ ンサで着座姿勢の状態を測定する。そして，感情推定の可能性を感 情判断因子得点とセンサ值との関係を重回帰分析で定量的に分析を 行う。手順として, 因子分析により着座姿勢に表出する感情判断因 子を抽出し, 各着座姿勢に対する感情判断因子得点と着座姿勢の画 像サンプル作成時に着座姿勢計測用圧力センサ（図 4 ・任天堂製 balance wii board）と加速度センサ（図 5 ・任天堂製 wii remote controller）のセンサ值を 30 秒間記録する。着座姿勢を測定するセ ンサは, 図 4 のソファの背もたれ, 座面, 脚部の各 4 箇所, 計 12 の圧力センサと，図 5 の左右の前腕および頭部後方に装着した 3 軸 加速度センサとした。圧力センサでは, 背もたれ部では上体の傾斜, 座面では, 臂部の位置, 脚部では脚部の傾斜を, 加速度センサでは, 首や腕の状態を測定する。この両方のセンサにより実時間でセンサ 值を測定する装置を着座姿勢計測システムと呼ぶことにする。

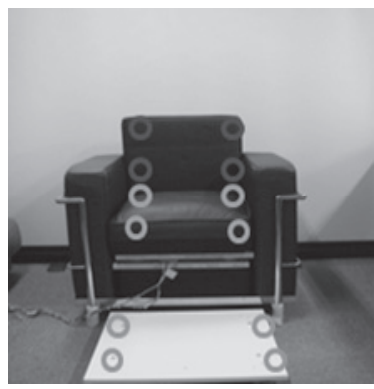

図 4 ソファによる圧力センサ内蔵着座姿勢計測システム

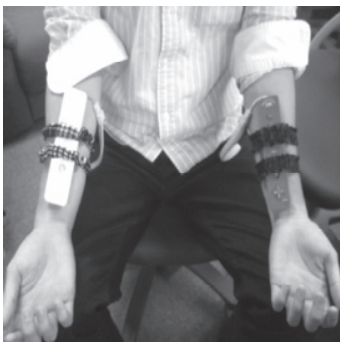

(a) 両腕部

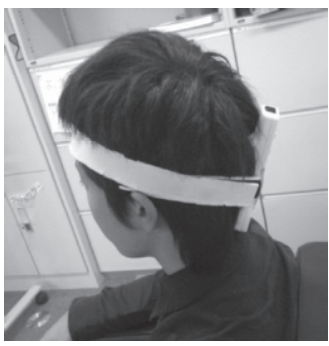

(b) 頭部
図 5 加速度センサを各部位に装着した状態 
感情判断因子得点を得るために, 実験 2 を行った。実験 1 との変 更点としては, 座りやすさを考慮して, 図 $1 \mathrm{~b}$ にあるようにンファ とした。ソファの背もたれおよび座面の下に圧力センサを設置した。 また, 観察者を新たに変更して, 因子の検証を再度行う。ここでは, 実験 1 と同様に感情判断因子を抽出し, 感情判断因子得点とセンサ 値による物理量との関係分析を行い, センサによる感情推定の可能 性を検証する。

\section{実験 2 内容}

観察者： 20 代前半 10 名（男性：8名，女性：2 名) サンプル：ソファ着座時の 24 着座姿勢（図 6 ) × 3 着座者 $(\mathrm{A}, \mathrm{B}$, $\mathrm{C})=$ 計 72 サンプル画像をランダムにディスプレー 上に表示

感情語： 実験 1 と同様

\section{2 感情判断因子抽出}

実験 1 と同様に, 72 着座姿勢サンプル画像 $(24$ 姿勢 $\times 3$ 名 $)$ に 対する 16 感情語について $1 \sim 7$ 点の評価值を割り当て, 全観察者 の平均值を用いて因子分析（主因子法）による着座姿勢の感情の因 子を分析した。固有值が 1 以上の 3 因子が抽出され, 各感情語の因 子負荷量（バリマックス回転後）から, 実験 1 と同様に 3 つの因子 を抽出し, 各着座姿勢の感情判断因子得点を計算した。

1. 覚醒度：「眠そうな」,「目覚めた」などの身体活動に関係す る感情

2. 快適度：「幸せな」,「悲しんだ」などの快・不快に関係する 感情

3. 支配度：「いらいら」,「怒った」など自分のパーソナル・ス ペースへの侵入に対する能動的に支配し、嫌悪する感情

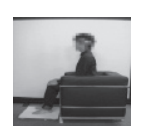

(1)直/前/垂

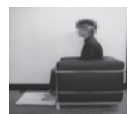

(7)直/後/後

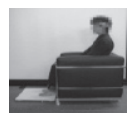

(13)後/後/垂

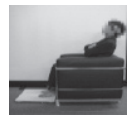

(19)(13)+後/胸 (20)(13)+前/胸

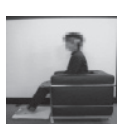

(2)直/前/投

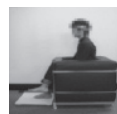

8)直/後/組

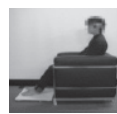

(14)後/後/投

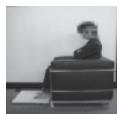

図 6

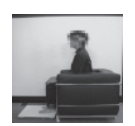

(3)直/前/後

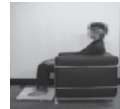

(9)後/前/垂

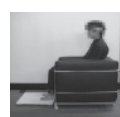

(15)後/後/後

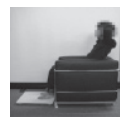

(21)(13)+後/頭

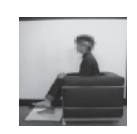

(4)直/前/組

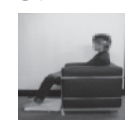

(10)後/前/投

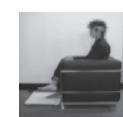

(16)後/後/組

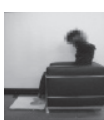

(17) (13) + 後

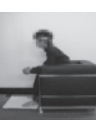

(18)(13)+前

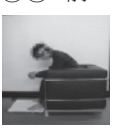

(6) 直/後/投

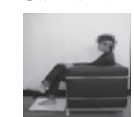

(12)後/前/組

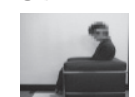

姿勢サンプル（実験 2 )

\section{3 感情判断因子得点と各センサ值との定量関係分析 \\ 3. 3. 1 圧カセンサのみの関係分析}

圧力センサのみで, 感情判断因子の推定可能性について分析を行 う。着座姿勢の 3 感情判断因子得点と, 姿勢画像サンプル作成時に
計測した各着座時の 12 個の圧力センサ值をもとに分析を行った。 具体的には, 各着座姿勢に対して, 独立変数は計測時の 12 個の圧 カセンサ值, 従属変数は「覚醒度」,「快適度」,「支配度」の各感情 判断因子得点として重回帰分析のステップワイズ法により分析を行 った。圧力センサ值は, 各姿勢を 30 秒間維持した状態で計測し, 30 秒間の平均值を使用した。重回帰分析により得られた各感情判 断因子の調整済み決定係数を参考にして分析を行う。

重回帰分析から,「覚醒度」に関して, 精度が高い結果となった反 面,「快適度」,「支配度」に関して, 精度が低い結果となった。この 原因としては，首，腕の状態が測定できないためと考えられる。

\section{3． 3．２圧カセンサと加速度センサの関係分析}

上記の結果をもとに，首と腕の状態を計測するため，図 5 に示す ように頭部と両腕に 3 軸加速度センサを計 3 台装着することで, 首 の傾き, 両腕の状態を計測する。加速度センサ計測值は, 各姿勢を 30 秒間維持した状態で計測し， 30 秒間の平均值を使用した。

各感情判断因子得点と着座姿勢計測システムの 12 個の圧力セン サ值と 3 台の加速度センサの $\mathrm{x}, \mathrm{y}, \mathrm{z}$ 軸の計 9 加速度センサ值 (- 1 (重力逆方向) 1 (重力方向)の值) との関係を重回帰分析のス テップワイズ法で分析を行った。例えば，頭部の $\mathrm{z}$ 軸（図 $5 \mathrm{~b}$ の後 頭部正面に対して垂直方向・手前が正）の加速度センサ值について は, 着座者 $\mathrm{A}$ の図 6 の首が直立(5), 後傾(19), 前傾(24)の姿勢において, それぞれ $0.00,-0.72,0.96$ となり, 直立を $0^{\circ}$, 直立より前傾をプ ラスとした角度に換算すると， $0^{\circ} ，-65^{\circ} ， 86^{\circ}$ となる。頭部の $\mathrm{y}$ 軸（図 $5 \mathrm{~b}$ の後頭部の水平断面に対して垂直方向・上が正）の加速 度センサ值については，直立が-1，前後の傾きが同様にマイナスと なり，前後の首の傾きの絶対值となる。重回帰分析により得られた 各感情判断因子の調整済み決定係数（表 2 ）を参考にして分析を行 う。ただし,変数間の高相関を排除するために共通性の診断を行い, 共通性が高い変数は独立変数から除外した。ここで, 姿勢を取る人 によって, 圧ンンサ值が異なることから, 各着座者のデータも分 析した。

ステップワイズ法（変数投入 $\mathrm{F}$ 值有意確率： 0.05 , 変数除去 $\mathrm{F}$ 值 有意確率：0.1）で得られたセンサ部位に対応する身体部位属性から 感情判断因子との関係を分析する。表 2 の有意な要因欄に, 上記条 件のもと独立変数として得られたセンサ部位名と標準化偏回帰係数 を括弧内に示す。部位名の表記に関しては,「背上・下」は背もたれ の上・下部,「座前・後」は座面の手前・後乃,「脚前・後」は脚部 の手前・後ろの左右どちらかの圧力セン少值, 「右腕・左腕・頭 $\mathrm{x}$ ・ $\mathrm{y} \cdot \mathrm{z} 」$ は右腕・左腕・頭部の $\mathrm{x} \cdot \mathrm{y} \cdot \mathrm{z}$ 軸の加速度センサ值を表す。

さらに表 2 の有意な要因の身体部位表記に関して,「体」は上体を 意味し、背もたれの 4 つの圧力センサの内一つでも関係する場合は, 上「体」の角度と関連すると解釈した。「臀」は臂部を意味し、座面 の 4 つの圧力センサの内一つでも関係する場合は,「慰」部の位置と 関連すると解釈した。「脚」は脚部を意味し、脚部の 4 つの圧力セン サの内一つでも関係する場合は，「脚」部の位置（角度）と関連する と解䣋した。首」は首部を意味し, 首部に装着した 3 軸加速度セン サの内一つでも関係する場合は, 「首」部の角度と関連すると解釈し た。「腕」は片腕もしくは両腕を意味し, 両腕に装着した 3 軸加速度 センサの内一つでも関係する場合は,「腕」部の状態と関連すると解 
表 2 各因子における調整済決定係数と身体部位との関係 (ソファ)

\begin{tabular}{|c|c|c|c|c|c|c|}
\hline 因子 & 着座者 & 決定係数 & \multicolumn{4}{|c|}{ 有意な要因 } \\
\hline 覚醒度 & 着座者 $\mathrm{A}$ & 0.468 & 体：角度 (背下：-0.70) & & & \\
\hline & 着座者 $\mathrm{B}$ & 0.781 & 体：角度 (背上:0.86) & 腕 (右腕 X: - -0.31) & 慰 (座後: -0. 27) & \\
\hline & 着座者C & 0.825 & 体：角度 (背上:0.54) & 首：角度 (頭y：-0.55) & 跙 (座後: -0. 38) & 脚 (脚後: -0.32 ) \\
\hline & 全員 & 0.601 & 体：角度 (背上: 0.44 , 背下: -0.38 ) & 首：角度 (頭y：-0.29) & 腕 (右腕 X:-2.2) & \\
\hline 快適度 & 着座者 $\mathrm{A}$ & 0.704 & 首：角度 (頭 $\mathrm{z}: 0.83$ ) & 脚 (脚前: -0.30 ) & & \\
\hline & 着座者 $\mathrm{B}$ & 0.644 & 脚 (脚前: -0.32 ) & 腕 (左腕y: -0.29$)$ & 首：角度 (頭z:0.68) & \\
\hline & 着座者C & 0.568 & 首：角度 (頭z:0.66) & 臂（座前：-0.41） & & \\
\hline & 全員 & 0.593 & 首：角度 (頭z:0.72) & 脚 (脚前: -0.37 ) & & \\
\hline 支配度 & 着座者A & 0.630 & 脚 (脚前：-0.64) & 腕 (右腕y: -0.53 ) & 臂 (座後: -0.46 ) & \\
\hline & 着座者B & - & & & & \\
\hline & 着座者C & 0.338 & 腕 (右腕y:-0. 61) & & & \\
\hline & 全員 & 0.353 & 腕 (右腕y: -0. 62, 左腕z: -0. 28) & 首：角度 (頭y: -0.21$)$ & & \\
\hline
\end{tabular}

釈した。

重回帰分析の結果, 腕や頭部に 3 軸加速度センサを装着したため, 圧力センサのみの場合に比べ, 首, 腕の状態が計測され, 「覚醒度」,

「快適度」に関係する着座姿勢の部位の状態を計測する事が可能に なった。一方,「支配度」については, まだ, 着座者ごとに決定係数 にばらつきがある。図6 からソファ側部が慰部の位置を隠している ことが一因として考えられる。あるいは，圧力センサと臂部の間に 座面用の厚いクッションがあることにより, センサ值の精度が落ち ている可能性もある。

まとめると，

「覚醒度」は，上体あるいは首の角度

「快適度」は，首の角度および脚の状態

「支配度」は，腕などの部位の状態

と関係があることが示唆された。

よって，精度向上を目指し，次の実験では，側面の慰部が見え， かつ, 圧力が直接伝わるパイプ椅子を用いて再度，実験を行うこと とした。

\section{4. 実験 3 : 感情判断因子と物理量との関係モデル化}

\section{1 実験目的および内容}

実時間で感情を推定するためのモデル式を構築するために，実験 1, 2 と同様にモデル化の学習データ用の実験を行った。実験 2 の 変更点としては, ソファ着座時では, 慰部の位置が分かりにくい点, 座面の圧力センサ精度が落ちる点を考慮して, 再度, パイプ椅子に 座りやすさを考慮して, 図 $7 \mathrm{a}$ にあるように座面と背もたれに薄い クッションを追加した。また, 実験 2 の加速度センサのサイズが大 きく精度が落ちるので, 図 $7 \mathrm{~b}$ のように小型のより精度の高い加速 度センサ(ATR-Promotions 製・WAA-010)に変更した。また, 観察 者の人数を増やし, 着座者も新たに変更してモデルの精度の検証を 行う。ここでは, 感情判断因子得点とセンサ值による物理量との関 係モデル化を行い，センサによる感情推定の可能性を検証する。具 体的には，学習データとして本実験データを用い，実時間感情推定 のモデル式を構築する。

\section{実験 3 内容}

観察者：20 代前半 28 名（男性：26名，女性：2 名)
サンプル：実験 1 と同様のパイプ椅子着座時の 24 着座姿勢 $\times 3$ 着座者 $(\mathrm{D}$ (身長 $171 \mathrm{~cm} /$ 座高 $87 \mathrm{~cm}), \mathrm{E}$ (身長 $173 \mathrm{~cm} /$ 座 高 $92 \mathrm{~cm}$ ), $\mathrm{F}$ (身長 $174 \mathrm{~cm} /$ 座高 $85 \mathrm{~cm})$ ) =計 72 サンプ ル画像をランダムにディスプレー上に表示

感情語： 実験 $1 ， 2$ と同様

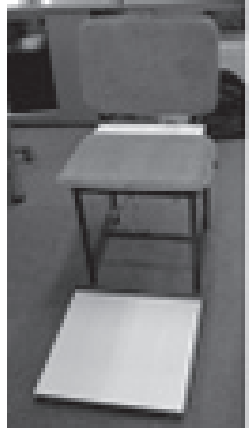

(a) パイプ椅子

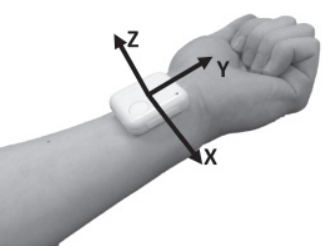

(b) 3 軸加速度センサ
図 7 実験 2 との変更点

\section{2 感情判断因子抽出}

実験 1,2 と同様に, 72 着座姿勢サンプル画像 $(24$ 姿勢 $\times 3$ 名 $)$ に対する 16 感情語について $1 \sim 7$ 点の評価值を割り当て, 全観察 者の平均值を用いて因子分析（主因子法）を用いて他者による着座 姿勢の感情判断因子を分析した。固有值が 1 以上の 3 因子が抽出さ れ, 各感情語の因子負荷量（バリマックス回転後）から, 実験 1 , 2 と同様に 3 つの因子を抽出し, 各着座姿勢の感情判断因子得点を 計算した。因子の結果は, 実験 1 と同様になった。

\section{3 圧カセンサおよび加速度センサの関係分析}

圧力センサおよび加速度センサ計測值は，各姿勢を 30 秒間維持 し，計測を行い，30 秒の平均值を使用した。各着座姿勢について独 立変数は計測時の 12 個の圧力センサ值および両腕・首 3 箇所 $\mathrm{x} 3$ 軸の計 9 加速度センサ值 $(-1000$ (重力逆方向) 1000(重力方向)の 值), 従属変数は感情判断因子得点として重回帰分析のステップワイ ズ法により分析した。図 $7 \mathrm{~b}$ のセンサを後頭部に付着する。頭部の $\mathrm{z}$ 軸（後頭部正面に対して垂直方向・手前が正）の加速度センサ值 については，着座者 D の首が直立(5)，後傾(19)，前傾(44)姿勢におい て，それぞれ- $180 ，-820 ， 880$ となり，直立を $0^{\circ}$ ，直立より前傾 をプラスとした角度に換算すると， $-16^{\circ} ，-65^{\circ} ， 86^{\circ}$ となる。頭 
表 3 各因子における調整済決定係数と身体部位との関係（パイプ椅子）

\begin{tabular}{|c|c|c|c|c|c|c|}
\hline 因子 & 着座者 & 決定係数 & \multicolumn{4}{|c|}{ 有意な要因 } \\
\hline \multirow{4}{*}{ 覚醒度 } & 着座者D & 0.277 & 体：角度（背上：0.56） & & & \\
\hline & 着座者 $\mathrm{E}$ & 0.735 & 体：角度 (背上:0.58, 背下:0.61) & 首：角度 (頭z:0.49) & 脚 (脚後: -0.37 ) & \\
\hline & 着座者 $\mathrm{F}$ & 0.814 & 体：角度 (背上:0.67) & 首：角度 (頭 $\mathrm{y} ：-0.45)$ & 腕 (左腕 $\mathrm{x}:-0.40)$ & 臂 (座前 : -0.24) \\
\hline & 全員 & 0.617 & 体：角度 (背上:0.59, 背下:0.26) & 首：角度 (頭 $y:-0.33$, 頭 $z: 0.20$ ) & 腕 (右腕 $x, y, z: 0.16,-0.18,-0.38$ ) & \\
\hline \multirow{4}{*}{ 快適度 } & 着座者D & 0.890 & 首：角度 (頭 $y ：-0.79$, 頭 $x: 0.20$ ) & 脚 (脚後:0.17) & & \\
\hline & 着座者 $\mathrm{E}$ & 0.669 & 首：角度 (頭 $\mathrm{y}:-0.52)$ & 臂（座前：-0. 34） & 腕 (右腕 $\mathrm{y}: 0.28)$ & \\
\hline & 着座者 $\mathrm{F}$ & 0.559 & 首：角度 (頭 $\mathrm{y}:-0.76)$ & & & \\
\hline & 全員 & 0.726 & 首：角度 (頭y: -0.64 , 頭 $\mathrm{z}: 0.25$ ) & 腕 (右腕 $x:-0.22$ ) & 体：角度 (背上：-0.15, 背下:0.15) & \\
\hline \multirow{4}{*}{ 支配度 } & 着座者D & 0.794 & 腕 (右腕 $\mathrm{y}:-0.93$ ) & 首：角度 (頭z:0.80, 頭x:0.39) & 臂 (座後:0.43) & \\
\hline & 着座者 $\mathrm{E}$ & 0.699 & 腕 $($ 右腕 $\mathrm{y}:-0.74$, 左腕 $\mathrm{z}:-0.48$ ) & 慰（座前：-0.37) & & \\
\hline & 着座者F & 0.781 & 腕 (左腕 $\mathrm{y}:-0.82)$ & 首：角度 (頭 $\mathrm{z}: 0.44)$ & 臂 (座後:0.42) & \\
\hline & 全員 & 0.718 & 腕 (右腕y: -0.73, 左腕 $\mathrm{z}:-0.36$ ) & 慰（座前：-0.26） & 首：角度 (頭z：0.37) & 体：角度 (背上: -0.30$)$ \\
\hline
\end{tabular}

部の $\mathrm{y}$ 軸（図 $5 \mathrm{~b}$ の後頭部の水平断面に対して垂直方向・上が正） の加速度センサ值については, 直立が-1, 前後の傾きが同様にマイ ナスとなり，前後の首の傾きの絶対值となる。

表 2 と同様に, 重回帰分析の結果を表 3 に示す。ただし, 変数間 の高相関を排除するために共通性の診断を行い, 共通性が高い変数 は独立変数から除外した。ここで有意な要因は, ステップワイズ法 (変数投入 $\mathrm{F}$ 值有意確率：0.05, 変数除去 $\mathrm{F}$ 值有意確率：0.1）で 得られたセンサ部位に対応する身体部位属性から推定する。

着座者 Dの「覚醒度」を除き, 精度が向上した。実験 2 との結果 の違いを見ると,「快適度」は腕の状態が関係し，「支配度」は，慰 部の位置が関係することが新たに分かった。支配度」については精 度が向上した。原因は, 座面の圧力センサ值との関係があり, 壂部 の位置（前縁か後縁）が重要であることが分かる。

まとめると，

「覚醒度」は，上体あるいは首の角度

「快適度」は，首の角度および腕・脚の状態

「支配度」は，腕の状態および臀部の位置

と関係があることがわかる。

\section{5. 実験 4：実時間感情推定システムの構築と評価 \\ 5. 1 感情判断推定值算出方法}

感情推定に関しては, 直接感情語を提示した方が分かりやすいと 判断したため, ここでは, 感情語推定を行い, 感情判断推定システ ムを構築・評価した。感情判断推定システムは, 実験 3 に用いたパ イプ椅子型の着座姿勢計測システムより出力される 12 圧力センサ 值および 9 加速度センサ值を重回帰分析のステップワイズ法で得ら れた重回帰式に代入することで感情判断を推定する仕組みを持つ。 表 3 に示すように, 3 着座者全員での重回帰式では推定精度が落ち るため, 各着座者の重回帰式を用いることにした。重回帰式の精度 を確認するために, 学習データとして実験 3 によって得られた各着 座者に対する 16 感情語による評価值と 12 圧力センサ值および 9 加速度センサ值との間の重回帰分析（ステップワイズ法）を行い, 調整済み決定係数 0.6 以上の感情語を表 4 に示す。ここでは, 決 定係数の高い感情語の推定精度を評価することにした。よって, 着 座者 $\mathrm{D}, \mathrm{E}, \mathrm{F}$ は，それぞれ $8 ， 10 ， 12$ 感情語を推定するになる。 感情判断推定システムは， 50 ミリ秒ごと更新される 12 圧力セ ンサ值および 9 加速度センサ值を計測值として, 重回帰式（例えば 式(1), (2)) に代入され, 感情判断推定值 y として実験で用いた感情
語尺度と同様な 1 （感情あり）から 7 （感情なし）の間で数値が出 力される。

感情判断推定值算出のための重回帰式例 :

- 不満足な $($ 着座者 D)の推定值 $\mathrm{yD}$ unsatisfied $=5.366+0.254 \times$ 背上左 (圧力) $-0.002 \times$ 頭 $\mathrm{Y}$ 軸(加速度) $+0.001 \times$ 右腕 $\mathrm{Y}$ 軸 $($ 加速度)

・驚いた (着座者 $\mathrm{E}$ )の推定值 $\mathrm{yE}$ suprised=2.512-0.23×背下右 $($ 圧力) $-0.175 \times$ 脚前(圧力) $-0.001 \times$ 左腕 $\mathrm{Y}$ 軸 $($ 加速度)

\section{2 学習による感情判断推定システム評価実験}

感情判断推定システムから出力される感情判断推定值 $\mathrm{y}$ の 30 秒 間の平均值を感情判断推定值 $\mathrm{Y}$ とする。ここで評価を単純化するた

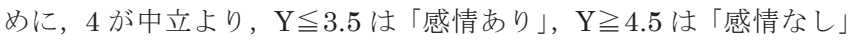
とした。感情判断推定システムの評価実験では, 実験 3 の各着座者 に実験と同様な 24 着座姿勢と未知の 6 着座姿勢の計 30 着座姿勢 をしてもらい, その時のセンサ值を保存する。同時に新たな評価者 3 名に各感情語による 7 段階評価を行った。

\section{実験 4 内容}

評価者： 20 代前半男性 3 名

サンプル：実験 3 と同様な 24 着座姿勢十未知の 6 着座姿勢（図 8 ）計 30 サンプル×着座者 3 名 $(\mathrm{D}, \mathrm{E}, \mathrm{F})=$ 計 90 着座姿勢サンプル

感情評価 : 実験 3 と同様に 16 感情語を用いた 7 段階評価
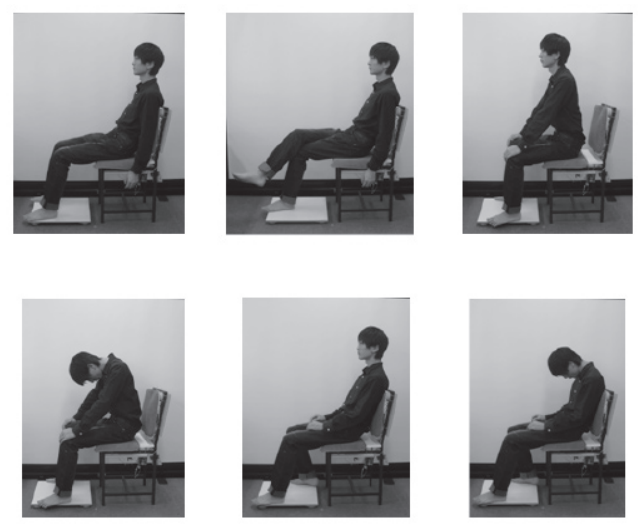

図 8 未知の追加着座姿勢

3 名の評価者の感情評価值を $\mathrm{Y}^{\prime}\left(1 \leqq \mathrm{Y}^{\prime} \leqq 7\right)$ とすると, 感情判断が あいまいと思われる「中立」值 4 の感情評価を除き，Y’ $\leqq 3.5$ は「感 
情あり」, $\mathrm{Y}^{\prime} \geqq 4.5$ は「感情なし」とした。感情判断推定值 $\mathrm{Y} \leqq 3.5$ かつ感情評価值 $Y^{\prime} \leqq 3.5$ の場合, あるいは, 感情推定値 $\mathrm{Y} \geqq 4.5$ か つ感情評価值 $Y^{\prime} \geqq 4.5$ の場合を正答とした。よって, 各感情の着座 者 3 名（ただし，感情語によって人数は異なる）の着座姿勢の感情 判断推定值による「感情あり」,「感情なし」の正答率は表 4 のよう になった。「驚いた」,「喜んだ」,「興奮した」などの「覚醒度」の高 い感情語の精度が $80 \%$ の正答率となり,「悩んだ」,「悲しんだ」な どの「快適度」が低い感情語, および,「悩んだ」,「悲しんだ」など の受動的な「支配度」は正答率 $60 ， 70 \%$ となった。その他の感 情語は推定が困難であった。

さらに, 全 24 サンプルに対して実験 3 の 28 名の観察者平均值 による「感情あり」、「感情なし」と実験 4 の 3 名の各評価者の感情 評価值による「感情あり」、「感情なし」の一致度を示す。正答率の 精度が劣る感情語は, 一致度が低いことがわかる。よって, 観察者 と評価者を同一人物にすれば正答率が上がると考えられるが，一般 化が今後の課題となった。

表 4 各感情語における正答率と学習データ一致度

\begin{tabular}{|c|c|c|c|c|c|c|c|}
\hline \multirow{2}{*}{ 因子 } & \multirow{2}{*}{ 感情語 } & \multicolumn{3}{|c|}{ 調整済み決定係数 } & \multirow{2}{*}{$\begin{array}{l}30 \text { サン } \\
\text { プル(\%) }\end{array}$} & \multirow{2}{*}{$\begin{array}{l}\text { 未知6サ } \\
\text { ンプル }(\%)\end{array}$} & \multirow{2}{*}{\begin{tabular}{|c} 
学習データータ \\
とのー致 \\
度(\%)
\end{tabular}} \\
\hline & & 姿勢者D & 姿勢者 $\mathrm{E}$ & 姿勢者F & & & \\
\hline \multirow{3}{*}{ 覚醒度 } & 驚いた & & 0.61 & 0.623 & 86 & 89 & 86 \\
\hline & 興奮した & & & 0.711 & 78 & 72 & 71 \\
\hline & 喜んだ & & 0.666 & 0.69 & 77 & 83 & 78 \\
\hline 快適度 & 悩んだ & 0.926 & 0.949 & 0.888 & 71 & 76 & 72 \\
\hline 支配度 & 怒った & 0.627 & 0.801 & 0.707 & 63 & 76 & 63 \\
\hline 快適度 & 悲しんだ & 0.956 & 0.798 & 0.826 & 62 & 54 & 71 \\
\hline 覚醒度 & 眠そうな & 0.886 & 0.737 & 0.857 & 53 & 56 & 67 \\
\hline \multirow{2}{*}{ 支配度 } & いらいら & 0.685 & 0.845 & 0.787 & 53 & 54 & 49 \\
\hline & 緊張した & & & 0.882 & 49 & 44 & 63 \\
\hline \multirow{2}{*}{ 覚醒度 } & 飽きた & 0.637 & 0.899 & 0.79 & 44 & 33 & 62 \\
\hline & 目覚めた & 0.694 & 0.797 & 0.796 & 42 & 43 & 47 \\
\hline 支配度 & 不満足な & 0.737 & 0.783 & 0.603 & 36 & 26 & 41 \\
\hline
\end{tabular}

\section{6. まとめ}

本研究では，着座姿勢において，顔の表情や立位姿勢と同様に， 「覚醒度」,「快適度」の因子が存在することが分かった。さらに, 姿勢に関しては，立位姿勢での「防御度」と似ている因子として「支 配度」が抽出された。ただ，第 3 因子については，まだ，解釈に難 点があるが, 従来研究[15][16]との同様な結果となり, 本実験の観 察者に関しては, 解釈されていることは分かった。着座姿勢への感 情判断となる身体状態は, 図 3 の感情判断因子得点分布, 表 2,3 の身体部位との結果から,

「覚醒度」は，主に上体および首の角度十腕の状態

「快適度」は，主に脚および首の角度十腕の状態

「支配度」は，主に腕の状態および壂部の位置＋脚組＋首の角度

と関係することが示唆された。よって, 感情判断因子によって下線 部に示すように，主に見る部位が異なる一方，腕や首などはすべて の感情判断因子に関係していることがわかる。

本研究において, 被験者数が少ない点など, 検討すべき点が残る。 ただ，因子に関しては，実験 $1 ， 2 ， 3$ を通して同じ因子が出現す る点, ソファを用いた正面の着座姿勢の実験結果も同様な結果が出
ている点などから，信頼度はあると考える。しかし，この感情判断 因子は，日本人の観察者による判断のため，例えば，他の文化圏の 観察者と同様になるとは限らない。注意が必要である。

また，感情判断の個人差に関しては，Kleinsmithと Bianchi-Berthouze[10]は，8名の観察者に 5 度の同じ主観評価実験 を行い, そのデータを分けて感情判断の一致度の分析を行っており, 一致度がかなり低い感情語が存在することを明らかにしている。本 研究でも，実験 $1 ， 2 ， 3$ の各感情語の各観察者間の標準偏差を分 析した結果,「不満足な」,「いらいら」,「落ち着いた」などの感情語 において高い標準偏差となり，観察者間で統一的な解釈を持てない 感情がある可能性がある。これらの感情語は，表 4 の学習データの 一致度の低い感情語と一致し，個人差があることが示唆される。今 後の課題としたい。

着座姿勢の状態を測定するために，導入したセンサが役立つこと が分かったが，感情推定に関しては，圧力センサのみでなく，加速 度センサを追加することで精度が上がることが分かった。しかし， 加速度センサはユーザが装着する必要があるため, 首, 腕の状態を 測定可能な非接触式のセンサ(例えばkinect)を今後導入していく。

実時間の感情推定に関しては, 感情語によって正答率が異なるが, 汎用的なモデル化が困難であった。また，今回は，着座者の個人の センサデータを用いたので，センサデータの標準化手法を導入して すべての人のモデル化手法を構築し, 精度の高い感情推定を行うシ ステムを構築していく。

\section{謝辞}

本研究は JSPS 科研費 22500190 の助成を受けたものです。本研 究を進めるにあたり，内藤太郎君，木島洋平君のアイディアが基盤 となっており, さらに, 研究室メンバーやアンケート調査を行って いただいた方々の協力により, 本成果を生み出すことが出来ました。 ここに感謝の意を表します。

\section{参考文献}

1) S. Baron-Cohen: Mindblindness, MIT Press, 1995.2

2) P. Ekman: Facial Expression and Emotion, American Psychologist, Vol. 48, No. 4, pp. 384-392, 1993.4

3) J. A. Russell: A circumplex model of affect, Journal of Personality and Social Psychology, Vol. 39, No. 6, pp. 1161-1178, 1980.12

4）竹内将吾，酒井あゆみ，加藤昇平，伊藤英則：対話者好感度に基づく感性 会話ロボットの感情生成モデル，日本ロボット学会誌，Vol.25, No. 7, pp. 1125-1133，2007

5）坂本博康，坂田年男，井上光平，浦濱喜一：顔画像解析による人間の 快・不快の計測手法, 電子情報通信学会技術研究報告 (パターン認識・メデ イア理解), Vol. 106, No. 230, pp. 1-8, 2006.9

6) A. Vrij, K. Edward, and R. Bull: People's insight into their own behaviour and speech content while lying, British Journal of Psychology, Vol. 92, Issue 2, pp. 373-389, 2001.5

7) 渡辺秀俊, 安藤正雄, 高橋鷹志: 着座場面における姿勢の経時的変化: 人間環境系における着座姿勢の働態に関する研究(第 1 報)，日本建築学会計画 系論文集, No. 474, pp. 107-114, 1995.8

8）小林茂雄，村中美奈子：飲食店でとられる着座姿勢の特徵，日本建築学会 環境系論文集, Vol. 73, No. 634, pp. 1341-1346, 2008.12

9 ) A. Kleinsmith and N. Bianchi-Berthouze: Recognizing Affective Dimensions from Body Posture, Proceedings of the Int. Conf. of Affective Computing and Intelligent Interaction, LNCS 4738, pp. 48-58, Lisboa (Portugal), 2007

10) A. Kleinsmith and N. Bianchi-Berthouze: Recognizing Affective 
Dimensions from Body Posture, IEEE Transactions on systems, man, and cybernetics-part B: Cybernetics, Vol. 41, No. 4, 2011.8

11) 鶴岡功, 橋本直朋, 坂本砂季子: シート座り心地性能の定量化, マツダ 技法, vol. 3, pp. 95-103，1985

12) M. Kolich: Predicting automobile seat comfort using a neural network,International Journal of Industrial Ergonomics, Vol. 33, pp.285-293, 2004

13）藤巻吾朗：体圧分布のパターン変動と座り心地, 早稲田大学大学院博士 論文, 2005. 1

14) S. Mota and R.W. Picard: Automated Posture Analysis for Detecting Learner's Interest Level, Workshop on Computer Vision and Pattern Recognition for Human-Computer Interaction (CVPR HCI), Vol. 5, pp. 49-54, 2003.6

15）柴田滝也, 木島洋平、深町翔太：着座姿勢による感情推定手法に関する 研究一正面と側面の姿勢の比較分析一, 2012.3

16）柴田滝也：他者から見た着座姿勢の感情分析と推定システムに関する研 究, 日本建築学会大会学術講演梗概集(情報システム技術) pp. $51-54$, 2012.9

（2013年 2 月 4 日原稿受理，2013年 4 月 12 日採用決定） 